\title{
The Situation of Women of a Refugee and Immigrant Background in the Netherlands
}

\begin{abstract}
The problem of discrimination and unequal treatment of women from culturally diverse backgrounds affects countries such as the Netherlands. The centuries of tolerance and openness to an "alien" seem to be ending. This is evidenced by numerous reports and scientific studies, statements from specialists, and experts on the issues of immigrant integration. Increasingly, feeling marginalised and deprived of development opportunities, immigrant or refugee women come to the fore. Some of them (those remaining in isolation) are represented by aid organisations, i.e. foundations, associations, volunteer groups, and the municipalities themselves. This article covers the existing issue of the increasing number of refugees and immigrants in the Netherlands, especially refugee and immigrant women towards whom, according to specialists, integration policy should be redefined.
\end{abstract}

Keywords: Refugees, Women, Immigrants, Discrimination, Integration, Labour Market, Emancipation, Netherlands

\section{Introduction}

In the debate on the integration of ethnic minorities, the topic of refugee women is still little exposed. Research shows that it is they who need much more support from the host society than men from the same environment. ${ }^{1}$ Since the arrival (considered to have reached a peak in the years 2014-2015) of a large number of refugees in the Netherlands, the problems of their integration and forms of assistance from, among others,

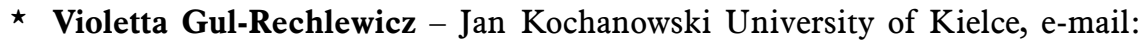
violetta.gul-rechlewicz@ujk.edu.pl, ORCID: 0000-0002-6471-2395.

${ }_{1}$ M. Maliepaard, B. Witkamp, R. Jennissen, Een kwestie van tijd? De integratie van asielzoekers: een cohortonderzoek, CAHIER, 2017-3, WODC, Den Haag 2017. 
state institutions, municipalities or organisations working for the benefit of ethnic minorities have been present. Although these bodies have been working hard on the integration and professional activation of the newcomers, these actions are still insufficient. As shown by a 2017 monitor of the city's refugee employment support policy ("Monitor gemeentelijk beleid arbeidstoeleiding vluchtelingen 2017 ”), for $37 \%$ of them (i.e. $2 / 5$ of people with the right to stay in the Netherlands) fully satisfactory operating procedures concerning integration in the labour market have not been implemented yet. ${ }^{2}$ It seems, for example, that the lack of distinction between the sexes in municipal strategies and in projects concerning the employment policy of immigrants (including refugees) in effect leads to asymmetrical results between women and men to the evident detriment of the position of women. Women, as will be presented in this text, are in a less favourable position than men already at the first stage of the integration process. Their position does not substantially improve with time. Nevertheless, the awareness that immigrant/refugee women deserve attention is gradually increasing in the Netherlands. ${ }^{3}$ This is evident due to the increasingly frequent initiatives by governmental and nongovernmental institutions which are aimed particularly at women from culturally diverse backgrounds. Several projects have been carried out to strengthen the social position of this particular group of women, develop their talents, and support the initiatives in which they are involved. ${ }^{4}$

The key research questions in this paper boil down to three: (1) are immigrant/refugee women treated in the same way as immigrant/refugee men? (2) What barriers limit the participation of female immigrants/ refugees in the labour market? (3) Is the gender-specific element taken into account in career guidance for ethnically diverse groups?

The article is (mostly) based on Dutch literature on the subject, reports, and analyses from the Dutch Central Bureau of Statistics, studies by the Social and Cultural Planning Agency (Sociaal en Cultureel Planbureau), and projects of non-governmental organisations dealing with the integration of ethnic minorities (mainly women) in the Netherlands.

2 I. Razenberg, M. Kahmann, M. Gruijter, Monitor gemeentelijk beleid arbeidstoeleiding vluchtelingen 2017, Kennisplatform Integratie en Samenleving, Utrecht 2017.

3 This text covers not only the problem of refugee women, but also provides a broader reference related to discrimination and unequal treatment as well as the stereotypical perception of women from culturally and religiously diverse backgrounds, i.e. economic immigrants and those female immigrants/refugees who joined their families settled in the Netherlands (nid. nereizigers).

4 A. Hinsberg, Emancipatiemonitor: vrouwen met een migratiegrond blijven achter, KIS, 12.12.2018, https://www.kis.nl/artikel/emancipatiemonitor-vrouwen-met-eenmigratieachtergrond-blijven-achter (access 15.02.2021). 


\section{Refugees in the Netherlands During the Migration Crisis}

\section{General information}

The Kingdom of the Netherlands, being a signatory to the European Convention on Human Rights (ECHR), protects those who flee war, violence, and inhuman and degrading treatment. The Dutch government, fulfilling its obligations towards those in need, gives them support and all due help. In the years that were considered the peak period of the refugee crisis, i.e. 2014-2015, refugees from North Africa, Syria and Eritrea, arrived in the Netherlands. There had not been particularly many asylum seekers in the Kingdom in the last twenty years until then. At a critical juncture in mid-September 2015, Klaas Dijkhoff, Secretary of State for Security and Justice, urgently mobilised all Dutch municipalities to prepare the necessary infrastructure to accommodate the multitude of asylum seekers. The reception was handled by the Central Agency for the Reception of Asylum Seekers (Centraal Orgaan Asielzoekers, COA) by arranging the necessary accommodation. From mid-September to the end of January 2016, 141 municipalities fulfilled their task, with an importantly large amount of support from volunteers and residents who displayed a civic initiative in helping refugees find their way in a new reality. ${ }^{5}$

In 2014-2015, the number of asylum applications more than doubled compared to previous years, placing the Netherlands at the fore of the European countries attracting the greatest number of refugees. In 2014, the number of applicants was 29,890, and in 2015 - 591,003, which clearly shows the spectacular increase in the number of applicants. The vast majority of refugees, about $70 \%$, were male, of whom $20 \%$ were minors. Women soon joined the group. This time they constituted the majority (approx. 60\%). ${ }^{6}$ Among the refugees applying for asylum in the Netherlands in those years, the most frequent were citizens of Syria and Eritrea (90\%). ${ }^{7}$ Importantly, from January 2013 to October 2016, these refugees, i.e. $42 \%$ of Syrians and $21 \%$ of Eritreans, received permission to stay in the Kingdom already at the first stage of the

${ }^{5}$ V. Wijkhuijs, M. van Duin, Vluchtelingencrisis 2015: Lessen uit de crisisnoodopvang, Instituut Fysieke Veiligheid, Arnhem 2017, passim.

6 From Refugees to Workers, Mapping Labour-Market Integration Support Measures for Asylum Seekers and Refugees in EU Member States, Volume II: Literature Review and Country Case Studies, Bertelsmann Stiftung 2016, p. 93.

7 Faarrapport Integratie 2016, Centraal Bureau voor de Statistiek, Den Haag/ Heerlen/Bonaire 2016, p. 40. 
application process. $^{8}$ Another wave, though smaller (17\% of Syrian citizens, $6 \%$ from Eritrea), came to the Netherlands in 2017. Iraqis (5\%) and Moldovans (5\%) constituted the remaining groups. ${ }^{9}$ In June 2017, mainly Syrians (63\%) and Eritreans (15\%) joined their families; so-called 'stateless people' accounted for $9 \% .^{10}$

At the same time, it is worth emphasising that a possibly unexpected new influx of migrants was still taken into account by the Dutch government. Therefore, reception centres in all Dutch municipalities had been made ready. ${ }^{11}$ It was assumed that the applicants would then apply for the family reunification program, which would inevitably increase the number of refugees in the short term. Leerkes and Scholten then raised the issue of the unforeseen situation in the Middle East which - as they suggested could generate a new stream of refugees. Some Dutch researchers state that the inflow of potential immigrants from Sub-Saharan Africa in the coming decades will be caused by structural changes, i.e. economic and demographic trends that take place in this area, generating an outflow of people from this region, especially from Cameroon, Nigeria, and Ghana. ${ }^{12}$ According to some specialists, a significant number of refugees will stay in the Netherlands permanently, contributing to the increase in the number of foreigners in this country. Hence, their reception and subsequent integration into Dutch society is so important.

Until recently, Razenberg et al. argued that in the Dutch integration debate, gender equality issues concerning immigration had been largely neglected. ${ }^{13}$ This situation is confirmed by labour market research

8 A. Leerkes, P. Scholten, Landen in Nederland. De vluchtelingenstroom in integratieperspectief, In opdracht van het Ministerie van Sociale Zaken en Werkgelegenheid, Rotterdam 2016, p. 6.

9 The figures obtained on 5.08.2017. For more details see V. Gul-Rechlewicz, Nauka, polityka, integracja. Kontrowersje wokót holenderskiej polityki, PU Compus, Kielce 2017.

10 Asylum Trends. Monthly Report on Asylum Applications in The Netherlands. Recent trends, Ministry of Security and Justice Immigration and Naturalisation Service (IND), IND Business Information Centre (BIC), Den Haag 2017, p. 5; https://ind.nl/ en/Documents/ATJune 2017.pdf (access 3.11.2020).

${ }_{11}$ Opvangcapaciteit COA voor eind 2017 naar 31.000 plaatsen, as of 26.04 .2017 (COA capture capacity to 31,000 places by the end of 2017, as of 26.04.2017), https://www.coa.nl/ $\mathrm{nl} /$ actueel/nieuws/opvangcapaciteit-coa-voor-eind-2017-naar-31000-plaatsen (access 2.01.2021).

12 A. Leerkes, P. Scholten, Landen in Nederland. De vluchtelingenstroom in integratieperspectief, In opdracht van het Ministerie van Sociale Zaken en Werkgelegenheid, Rotterdam 2016, pp. 6-7.

${ }^{13}$ I. Razenberg, M. Kahmann, M. de Gruijter, Monitor gemeentelijk beleid arbeidstoeleiding vluchtelingen 2017, Kennisplatform Integratie en Samenleving, Utrecht 2017. 
regarding the participation of representatives of ethnic minorities in it, with particular emphasis on the position of women. However, most studies do not indicate why this is happening, what the employment opportunities for immigrant women actually are and what possible barriers make it difficult for them to work. ${ }^{14}$ A 2017 study by Barslund et al. shows that non-Western,immigrant women (not refugees) living in European Union countries have a much lower share in the labour market than non-Western immigrants. ${ }^{15}$ The holds true for those countries where there has been an increased influx of refugees in recent years. The socalled "gender gap" seems to exist mainly among low-skilled immigrants, but as it is also worth mentioning that the very same situation exists among people who have a secondary or university education. A new study in Amsterdam confirms that women who have recently been granted the right to reside in the Netherlands are less likely to work than men with the same status. Refugee males also find employment faster than female refugees. It has been observed that during a period of three to five years of stay in the country, $33 \%$ of men find a job. By comparison, only $15 \%$ of women gain employment. ${ }^{16}$ Other studies show that after fifteen years of living in the Kingdom, only $45 \%$ of women from refugee backgrounds are offered employment for more than eight hours a week while in the case of indigenous Dutch women it accounts for $75 \%$, and for other female immigrants (so-called non-Western) it stands at about $62 \% .{ }^{17}$ This state may be partly explained by the fact that traditional divisions into male and female roles still exist in some ethnic groups. This is especially visible if we take the example of women with children who participate in the labour market to a small degree. Maliepaard et al. indicated that female refugees with the right of residence, compared to male refugees with the same status, have less contact with the indigenous people of the Netherlands. This form of isolation may be one of the reasons why these women find it difficult to find employment. It is also worth adding that immigrant women in situations such as the economic crisis are more exposed to the loss of jobs obtained earlier than men. ${ }^{18}$

14 Ibidem.

15 M. Barslund, A. Bartolomeo, L. Ludolph, Gender Inequality and Integration of Non-EU. Migrants in the EU, CEPS. Policy Insight, No. 2016/06, CEPS, Brussels 2017.

16 Gemeente Amsterdam. Vluchtelingenmonitor 2016. Gemeente Amsterdam, Afdeling Onderzoek, Informatie en Statistiek, Amsterdam 2016.

17 M. Maliepaard, B. Witkamp, R. Jennissen, Een kwestie van tijd? De integratie van asielzoekers: een cohortonderzoek, CAHIER, 2017-3. Den Haag: WODC, 2017.

18 Ibidem. 


\section{Social Status of Women from Immigrant Backgrounds}

Female representatives of ethnic minorities, as indicated above, are under-represented in Dutch society. Moreover, they occupy secondary positions as compared to men from the same backgrounds. As claimed by Eleonora Kofman, this mainly results from a culture which is very different from that represented by Western societies. ${ }^{19}$ Immigrant families, in which women have to act in obedience to their fathers, husbands, and brothers, often retain their traditions in response to the pressure of acculturation. Their native culture tends to be idealised, and its values, features, and customs have become a symbol of a stable identity. ${ }^{20}$

On the other hand, it is worth remembering that the attitude of the host societies characterised by the standards of their own culture may correlate with the behaviour discriminating against male/female immigrants in various important areas of integration, e.g. in the labour market. The financial independence of both adult female and male immigrants is often smaller than that of the indigenous inhabitants of the Netherlands. ${ }^{21}$ The clash of the original patriarchal culture with the liberal Western culture may be additionally strengthened by the resentment of the inhabitants of Western countries resulting from a history of colonisation, combined with the problems related to the dissatisfaction of part of the society with an increasing number of immigrants. ${ }^{22}$

As far as the non-Western women immigrants and the emancipation process in culturally "alien" environments (liberal Western culture) are concerned, several factors influence the success of this process. According to Barbara Pasamonik, these are [1] marital status (women migrating alone; women migrating as married women; unmarried daughters), [2] generation (the first who decided to emigrate; the second and third, who were born in the country of settlement), [3]education (illiteracy, language skills, general and vocational education), [4] gainful employment in the country of residence (families where the husband works and the wife does not; both the wife and husband work; neither the husband nor wife work), [5] culture of origin (rural/urban, the culture of origin compatible with the culture of settlement, culture clash, post-colonial

19 E. Kofman, Female "Birds of Passage" a Decade Later. Gender and Immigration in the European Union, "International Migration Review", no. 2(33)/1999.

${ }^{20}$ Ibidem.

${ }^{21}$ J. de Ridder, I. Andriessen, P. Dekker, Nederlanders dubel over discriminatie, „Burgerperspectieven”, no. 2/2017, Sociaal en Cultureel Planbureau, 29.06.2017, p. 36.

22 D. Jansen, Immigratie en integratie het grootste probleem van Nederland, https:// demonitor.kro-ncrv.nl/artikelen/immigratie-en-integratie-het-grootste-probleemvan-nederland (access 21.02.2021). 
resentment); 6] religion (practiced/hardly practiced, the same/different from the religion in the country of residence, tolerant/intolerant of other religions); [7] the attitude of the host society towards immigrants (racism/ tolerance is dominant); [8] the social status of a woman and a man in their own and host society (the status of a woman before emigration low, as an immigrant - higher; the status of a man before emigration high, as an immigrant - lower); [9] material status (low material status before emigration, higher status as an immigrant, low material status before emigration and as an immigrant); [10] type of settlement (ethnic ghettos, mixed up settlements); [11] immigration law (discrimination against women immigrants, discrimination against all immigrants); [12] immigration policy (multicultural policy / integration-oriented policy). ${ }^{23}$ The list of factors presented is undoubtedly long and complex, but it can be assumed, following Pasamonik, that three of them are of key importance for the emancipation of women from immigrant backgrounds (especially non-Western backgrounds): gainful employment providing autonomy, "post-colonial resentment" that may correspond to unequal treatment and civilisation and cultural code that prevents emancipation. ${ }^{24}$ It is also worth taking into account the fact that the situation of immigrant women is much more complex, given the differences related not only to the issue of gender but also to one's belongingness to a specific social class, race, ethnicity, and "alien" status. ${ }^{25}$

Thus, immigrant/refugee females coming to the Netherlands constitute a heterogeneous group by definition. This heterogeneity is related, inter alia, to their country of origin, level of education, professional experience, age, and family situation. Among them, there are those who want to become independent as soon as possible, but there are also those for whom the traditional division of duties, dependence on the father or husband are firmly embedded in their cultural code. It is also important that female asylum seekers are in a less favourable situation than women who came to the Netherlands as part of the so-called family immigration. The latter constitute a group much larger in number and, ${ }^{26}$ additionally, have the support of their relatives who came to the Kingdom earlier.

${ }^{23}$ B. Pasamonik, Women immigrants in Western societies. Emancipation and integration, https://www.academia.edu/17550426/Imigrantki_w_spo\%C5\%82ecze\%C5\%84stwach Zachodu._Emancypacja_i_integracja, p. 67 (access 23.02 .2021 ).

${ }^{24}$ Ibidem, pp. 67-68.

25 P. Pessar, S.J. Mahler, Transnational Migration: Bringing Gender, "International Migration Review", vol. 37, pp. 812-846.

${ }_{26}$ The Netherlands hosted 28,200 asylum seekers and 190,900 family migrants (as of 2018), in: Ministerie van Onderwijs, Cultuur en Wetenschap, Emancipatie, Verschillende groepen vrouwen op de arbeidsmarkt, Den Haag 2018. 
Effective integration of women from ethnically diverse backgrounds requires knowledge of the culture of the country from which immigrant/ refugee women come. It also entails an increased effort on the part of all Dutch municipalities and institutions cooperating with them. It is up to them to decide whether the chosen strategy/direction of local policy will be successful or doomed to failure. According to numerous studies and reports, the integration of ethnic minorities in the labour market, a key area of integration, is highly unsatisfactory in the Netherlands. ${ }^{27}$ Female immigrants/refugees constitute a group that needs a special kind of support. Ghorashi - an Iranian political refugee woman and cultural anthropologist - points to errors which have been systematically occurring in the policy towards immigrant/refugee women in the Netherlands for years, and which lead to isolation rather than integration into Dutch society. As the researcher claims, too much attention is paid to assimilating these women into the Dutch culture, rather than exploring the culture they come from. ${ }^{28}$ Knowing how to function, for example, on the labour market, would help both women representing non-Western culture to find themselves in the new reality and the Dutch society, thereby making the presence of women immigrants an asset. ${ }^{29}$ Additionally, trainers running educational workshops misinterpret the behaviour of women representing non-Western cultures considering it as passive and uncooperative. However, as it should be emphasised, the group of new arrivals is strongly diverse, have different attitudes, different desires, and priorities. As Ghorashi emphasises, unjust and harmful for many groups of women who come to the Netherlands is their marginalisation by aid institutions, ${ }^{30}$ excluding them from integration projects and organised workshops among other things. This is because in the Netherlands, more attention is devoted to the integration of women who mostly originate from Muslim diasporas. Other groups (e.g. black women, non-Muslim women) do not receive as much consideration. ${ }^{31}$ These groups are assumed to have already been emancipated.

${ }^{27}$ I. Razenberg, M. Kahmann, M. de Gruijter, “Mind the gap”: barrieres en mogelijkheden voor de arbeidsparticipatie van vluchtelingenvrouwen, KIS, Utrecht 2018, p. 3.

${ }_{28}$ Kennisuitwisseling Movisie en Refugee Academy, Vluchtelingenvrouwen en werk: 'kijk naar de mogelijkheden!, https://www.movisie.nl/artikel/vluchtelingenvrouwenwerk-kijk-naar-mogelijkheden (access 3.02.2021).

${ }^{29}$ Ibidem.

${ }^{30}$ Note: when writing about aid institutions, I take into account all entities (governmental and non-governmental, foundations, and associations) working for the integration of women from ethnically diverse backgrounds.

${ }_{31} \mathrm{H}$. Ghorashi, Culturalisering van de emncipatievan migrantenvrouwen, p. 5, http:// hallehghorashi.com/nl/wp-content/uploads/2010/12/Culturalisering-emancipatiemigrantenvrouwen.pdf (access 12.02.2021). 
The paper further discusses the main difficulties in the integration of immigrant/refugee women, as well as the critical position of Halleh Gorashi towards the policy concerning women already settled in the Netherlands - representatives of cultures other than Western culture.

\section{Barriers to Integration: Ethnic Minorities and the Labour Market}

\section{The Dutch Approach to Immigrants - Changing Attitudes?}

According to a survey by Ipsos, the majority of Dutch people (55\%) believe that the number of immigrants living in the Netherlands is too high. ${ }^{32}$ Other studies indicate that representatives of minority groups are more discriminated against now than they were twenty years ago. ${ }^{33}$ It is worth noting that discrimination is perceived as a serious problem in Dutch society, especially when considering the last few years. The phenomenon of unequal treatment, negatively perceived by the majority of Dutch people (68\%), is especially visible on the labour market and, significantly, in recent years - according to respondents - it is becoming more and more common. ${ }^{34}$ It is also important, given a certain asymmetry in the opinions of the Dutch, that $72 \%$ of surveyed Dutch residents believe that several situations defined as "discriminatory" are "exaggerated" and not always correspond to reality. ${ }^{35}$ This points to the lack of a clear definition of what discrimination and unequal treatment are. ${ }^{36}$

The ever-growing number of economic immigrants and refugees in the country has resulted in perceiving ethnic minorities and their integration as a major social problem by the Dutch. ${ }^{37}$ Mark Rutte's government does not seem to see the scale of the problem as, according to ECRI (European Commission Against Racism and Intolerance), the activities carried out by his government up to the time of this writing, aimed at combating discrimination based on skin colour, ethnic origin, and religion have not

${ }^{32}$ J. de Ridder, I. Andriessen, P. Dekker, op.cit., p. 36.

33 Ibidem.

${ }^{34}$ Ibidem.

35 H. van Dalen, Waroomwaant Nederland zich Europees kampioen discriminatie, http://www.mejudice.nl/artikelen/detail/waarom-waant-nederland-zich-europeeskampioendiscriminatie (access 22.02.2021).

${ }^{36}$ H. Obbink, K. van de Wetering, Over discriminatie hinken Nederlanders op twee gedachten, https://www.trouw.nl/nieuws/over-discriminatie-hinken-nederlanders-optwee-gedachten $\sim$ bb35b794/ (access 13.02.2021).

${ }^{37}$ H. Schmeets, M. van Hoof, Ontwikkelingen in ervaren nationale problemen, 2010 2014, Bevolkings trends, No 6, CBS, Den Haag 2016. 
proved effective enough. The Commission blames the State for the lack of specific and decisive actions to eliminate intolerant behaviour, the solution to which - as it claims - is shifted by the government to other institutions (e.g. municipalities or non-profit institutions). ${ }^{38}$ These, in turn, are not sufficiently prepared to fulfil their roles, which is shown, for example, in a report prepared by Kennisplatform Integraie en Samenleving (2018). ${ }^{39}$

In 2008, a study of 46 European countries showed that the Netherlands ranked first among the countries with the highest level of acceptance of newcomers (95\%). Nine years later, this level dropped to only $31 \% .{ }^{40}$ It seems that the current situation results from several factors, among which the most prominent, apart from the terrorist attacks in the United States and Europe, are incidents in the Netherlands itself (the murders of politician Pim Fortuijn and director Theo van Gogh are still remembered by the Dutch). Besides, the economic crisis, during which the unemployment rate in the Netherlands reached $6.6 \%$ in the critical year of $2013,{ }^{41}$ and the refugee crisis, which made the Dutch less tolerant towards "aliens", resulted in the intensification of anti-immigration and anti-refugee attitudes. It should be emphasised that it is precisely immigrants/refugees and their integration that are currently perceived as the biggest social problem in the Netherlands. ${ }^{42}$

Research shows that refugees are making little progress in key areas of integration, including the labour market. It is worth emphasising again that it is the labour market that is one of the basic areas of integration. In addition, the labour market is primarily responsible for incorporating newcomers. Compared to native Dutch people (but also to economic immigrants), refugees remain largely unemployed. If they are employed, their incomes are still lower than in the other groups mentioned. To a large extent, refugees are also beneficiaries of social institutions, living

${ }^{38}$ More in: Foundation for Political, Economic and Social Research, Istambul, Washington, Kair 2016.

39 I. Razenberg, M. Kahmann, M. de Gruijter, “Mind the gap”..., op.cit., p. 3.

40 H. Wansink, Zijn Nederlanders toleranter geworden tegenover migranten?, Volkskrant, 13.12.2017, https://www.volkskrant.nl/columns-opinie/zijn-nederlanders-toleranter-geworden-tegenover-migranten- $\sim$ bebf8a3f/ (access 16.02.2021).

${ }^{41}$ https://www.cbs.nl/nl-nl/nieuws/2017/16/werkloosheid-daalt-verder (access 22.01.2021). See also: T. Overdijk, Werkloosheid in Nederland hoger dan voor crisis, https://www.places.nl/nieuws/werving- $\&$-selectie/werkloosheid-in-nederland-hogerdan-voor-de-crisis/ (access 3.02.2021).

${ }^{42}$ M. Pacek, The Netherlands and the Migration Crisis, „Yearbook of the Institute of East-Central Europe", no. 3(15)/2017, pp. 55-72. See also D. Jansen, Immigratieen integratie het grootse probleem van Nederland, https://demonitor.kro-ncrv.nl/artikelen/ immigratie-en-integratie-het-grootste-probleem-van-nederland (access 21.02.2021). 
closer to the poverty line than other inhabitants of the country. ${ }^{43} 78 \%$ of the newcomers earn an income much lower than the average salary in the country, $26 \%$ live on the poverty line, and $46 \%$ work less than twelve hours a week. ${ }^{44}$ All this makes refugees the beneficiaries of social assistance, which makes this group dependent on benefits, which in turn contributes to the high degree of frustration characteristic for this group of migrants. Some non-governmental institutions dealing with the integration of ethnic minorities (e.g. VluchtelingenWerk Nederland, VWN; Stichting Vluchteling, SV $)^{45}$ suggest creating separate policies for adult male and female refugees. Since they constitute a specific group, separate strategies to facilitate their integration into Dutch society have been proposed. The important role of employment agencies to help newcomers find employment is underlined. ${ }^{46}$ The call for more intense actions towards them also means the activation of municipalities which should provide minority groups with a range of apprenticeships and vocational training. Bodies supporting the integration of immigrants address their suggestions mainly to the government to work more closely with active local centres and institutional partners to improve the situation of economic immigrants and refugees.

\section{“Trapped" in Their Own Culture?}

According to research and reports, the potential of adult male and female refugees is not fully exploited in the Netherlands. ${ }^{47}$ Obstacles resulting from both the specific cultural conditions of the newcomers and under-developed Dutch policy create a situation that increases the distance to the labour market for representatives of ethnic diasporas. Therefore, the position of refugees in the Netherlands requires redefinition, especially of women refugees, who seem to be the component most vulnerable to social exclusion for the reasons indicated previously, including their cultivation of traditional cultural roles related to gender hierarchy

${ }^{43}$ For more details see V. Gul-Rechlewicz, Udziat organizacji pozarzadowych w holenderskiej polityce wobec uchodźców. Rola Vluchtelingen Werk Nederland, PU Compus, Kielce 2017, pp. 105-107.

${ }_{44} \mathrm{Op}$ de arbeidsmarkt, http://www.werkwijzervluchtelingen.nl/feiten-cigejfers/arbeidsmarkt.aspx (access 22.03.2020).

45 V. Gul-Rechlewicz, Udziat..., op.cit., pp. 77-83.

${ }^{46}$ Ibidem, p. 83.

47 I. Razenberg, M. Kahmann, M. de Gruijter, “Mind the gap”..., op.cit., p. 3; Voortgangsrapportage. Emancipatie, maart 2019, Ministerie van Onderwijs, Cultuur en Wetenschap, https://www.womeninc.nl/Uploaded_files/Zelf/voortgangsrapportage-emancipatie-voor-de-tablet-of-smartphone-tevens-printversie-en-digitoegankelijk.b30c05.pdf (access 23.02.2021). 
and their having little (or no) professional experience. However, perceiving adult female immigrants, especially those who are non-Western, in this way (said to be stereotypical for many Dutch people, and reaching back to philanthropic traditions and tolerant attitudes towards those in need) may prove to be illusory. For the image of people in social isolation, waiting for help, "trapped" in their own culture, according to Rath, can be somewhat misleading. The Dutch traditions of the welfare state, which has always cared for "dependent people" in need of support, may translate today into the existence of a "background" generating false perceptions of the needs of immigrants in the Netherlands. ${ }^{48}$ It seems that this unwavering need to help those in need should look a bit different now in comparison to a few decades ago. An in-depth knowledge of foreign cultures, their evolution, generational changes, and the ubiquitous globalisation impose a need to change the approach to new immigration. Refugee women who have recently come to the Netherlands do not constitute a homogeneous group, as has already been mentioned. They represent various countries including Syria, Eritrea, Afghanistan, and Iraq. ${ }^{49}$ Their level of education and the employment rate in their countries of origin is much lower than that of the men in those countries. In Syria, for example, only $12 \%$ of women participate in the labour market. ${ }^{50}$ According to the Centraal Bureau voor de Statistiek, those who want to settle in the Netherlands most often come from this group. ${ }^{51}$ However, they have less professional experience than native Dutch women with similar qualifications. On the other hand, it is worth emphasising that refugees show greater diligence at work compared to other groups of women (including economic immigrants) participating in the Dutch labour market. ${ }^{52}$ Adult female representatives of non-Western culture, according to Razenberg, are not, however, perceived as the so-called "promising employee". ${ }^{53}$ This image of a mother/housewife is a significant obstacle for a Dutch employer when potentially hiring such a person. It is worth noting that, until recently, this problem also affected Dutch women. ${ }^{54}$ Ponzoni emphasises this fact

${ }^{48}$ J. Rath, Minorisering. De sociale con-structie van 'etnische minderheden', Sua, Amsterdam 1991.

${ }^{49}$ Centraal Bureau voor de Statistiek, Uit de startblokken. Cohortstudie naar recente asielmigranten, Den Haag 2018.

${ }^{50}$ Ibidem.

51 Centraal Bureau voor de Statistiek, Van opvang naar integratie. Cohortstudie van recente asielmigranten, Den Haag 2017.

52 Vluchtelingen vrouwen en werk: kijk naar, https://www.movisie.nl/artikel/vluchtelingenvrouwen-werk-kijk-naar-mogelijkheden (access 12.02.2021).

${ }^{53}$ Ibidem.

${ }^{54}$ Cf: M. Banaś, Ellen Key and the Swedish "House of Prosperity" (Folkhemmet), in: Women in Politics, Culturo in spectro, Kraków 2017, pp. 197-212; J.A. Radowicz, Equal 
by forwarding a hypothesis that certain ways of thinking in Dutch culture overlap with the culture of newcomers. Statistically, Dutch women are not as financially independent of men as women in other European countries. ${ }^{55}$

A separate, slightly different problem is posed by immigrant women who come to the Netherlands to join their families who already reside in this country. In some municipalities, the possibilities of supporting such women (Dutch: nereizigers) largely depend on the life trajectory of their spouses (fathers, brothers). If they are sufficiently fluent in Dutch and have the required professional experience (which is often the case), the women under their care can expect only minimal support from local authorities. As a result, it is especially newly-arrived refugee women are deprived of contact with the rest of the community. According to reports, this is happening mainly due to the lack of knowledge of the Dutch language and the feeling of being lost in a culturally foreign environment. Also, without a clearly "defined" professional identity, they focus primarily on the future of their children, thus postponing their own professional development or even giving it up entirely. It is the presence of children that is often mentioned by experts as one of the main obstacles preventing refugee women from securing employment. ${ }^{56}$ Other equally often mentioned reasons are the lack of professional experience, a low level of participation in vocational training/language courses, and the lack of social networks. ${ }^{57}$

\section{Multi-Stakeholder Type of Support for Women from Immigrant/Refugee Backgrounds}

\section{The Advantages and Disadvantages of Integration Projects}

Support for immigrants on the labour market from industry organisations, ${ }^{58}$ municipalities, or non-governmental institutions ${ }^{59}$ seems to be fully justified in the Netherlands. Almost everyone uses it,

Rights for Woman: Nordic Solutions, "Studia i Materiały. Miscellanea Oeconomicae", no. 2(18)/2014, pp. 283-297.

55 Vluchtelingenvrouwen en werk: kijk naar mogelijkheden, https://www.movisie.nl/ artikel/vluchtelingenvrouwen-werk-kijk-naar-mogelijkheden (access 12.02.2021).

56 I. Razenberg, M. Kahmann, M. de Gruijter, “Mind the gap”..., op.cit., p. 3.

57 Ibidem.

${ }^{58}$ E.g. LTO - Land en Tuinbouw Organisatie Nederland, TLN - Inbreng Transport en Logistiek, BDO38, FME - Feature Manipulation Engine, MKB - Midden en Kleinbedrijf.

59 E.g. UVW - Uitvoeringsinstituut Werknemersverzekeringen oraz VWN VluchtelingenWerk Nederland. 
from immigrants/refugees, because it is related to their activation on the labour market which, in turn, leads to their independence; municipalities because their budget is naturally relieved due to the limitation of the number of unemployment benefits (in this case for residents of immigrant origin); the economy that is boosted thanks to additional human capital, new jobs, and finally, society itself, which enhances its image.

Whether women from immigrant/refugee backgrounds participate in the labour market is not associated only with their origin or individual abilities, i.e. personal qualities, decision-making skills, and attitudes towards change. Aid institutions assisting in employment counselling play an important role in attracting future employees. Barslund points out that in many European countries, including the Netherlands, helping immigrants to find employment is mostly based on the limited scope of the problem of their employment (he calls it, "one size fits all”). As a result, the specific needs of potential employees and their suggestions for work are put aside or even not taken into account at all. ${ }^{60}$ This is evidenced by the previously mentioned example of newly arrived refugee women, especially those who are uneducated, but also those educated to a degree level ${ }^{61}$ According to most research studies, this is because these women, regardless of their education, invariably assume the traditional roles of wives and mothers, downplaying the importance of their professional development. ${ }^{62}$ This state of things, which is often emphasised by Dutch researchers, seems to speak for focusing more attention on gender-sensitive labour market management also concerning representatives of ethnic minorities living in the country, especially those of Muslim origin. It is worth bearing in mind the decades of efforts by the state to activate immigrant/refugee women who, due to an insufficient (or inadequate) level of education and having little interest in work outside the home, and/or slight (or no) contact with the Dutch society, do not participate in the labour market.

The previously-described traditions of assistance in the Netherlands find their justification in the attempts to increase the share of immigrant/

${ }^{60}$ M. Barslund, A. Bartolomeo, L. Ludolph, Gender Inequality and Integration of Non-EU Migrants in the EU. CEPS Policy Insight, no. 06/2016, CEPS, Brussels 2017.

${ }_{61}$ Vluchtelingen vrouwen en werk: kijk naar mogelijkheden, https://www.movisie.nl/ artikel/vluchtelingenvrouwen-werk-kijk-naar-mogelijkheden (access 12.02.2021).

${ }^{62}$ M. de Gruijter, S. ter Woerds, Kansen en belemmeringen bijmaatschappelijke participatie van hoger opgeleide vrouwelijkevluchtelingen, Vooronderzoek voor het project 'Barrière of Carrière?' 2005, pp. 9-15, https://www.verwey-jonker.nl/doc/participatie/D8071871_def.pdf (access 11.01.2021). See also M. de Gruijter, Hoe zorgen we dat vluchtelingenvrouwen net zo vaak werk inden als mannen?, https:/www.kis.nl/artikel/ hoe-zorgen-we-dat-vluchtelingenvrouwen-net-zo-vaak-werk-vinden-als-mannen (access 11.01.2021). 
refugee women in areas related to their integration into society. One of the most important projects, initiated by the Advisory Committee on the Participation of Women from Minority Groups (Participatie van Vrouwen uit Etnische Minderheidsgroepen, PaVEM), was carried out between 2003-2005 and aimed at promoting the participation of immigrant women in selected areas of social interaction. This initiative was so successful that the Ministry of Social Affairs and Employment (Ministerie van Sociale Zaken en Werkgelegenheid) followed the recommendations of PaVEM in the "Emancipation and Integration Action Plan" ("Plan van aanpak emancipatie en integratie"). ${ }^{63}$ Another project, entitled "Barriere of Carriere?", was carried out in the following years (2005-2007) with the participation of the UAF (University Assistance Fund). It was aimed mainly at women with a university education and its objective was to increase their participation in the labour market. ${ }^{64} \mathrm{~A}$ subsequent project, "1001 Kracht", on behalf of the Ministry of Education, Culture and Science (Ministerie van Onderwijs, Cultuur en Wetenschap, OCW), aimed to activate 50,000 women from minority backgrounds. As part of this initiative, immigrant women were encouraged to get involved in social life, including by participating in voluntary activities aimed at motivating the participants of the project to take part in professional training and then take up paid work. The abovementioned projects targeted a group of women of immigrant origin who maintained their distance from Dutch society, regardless of how long they had stayed in the Netherlands. The projects were not fully successful, since they also activated women who, when the projects started, were completely unknown to the wider local community, and did not have any employment contract. Moreover, these long-term initiatives performed two functions simultaneously: on the one hand, they strengthened the position of women, and, on the other hand, they contributed to developing or improving the already existing employment assistance services.

Currently, there are many projects aimed at activating women from culturally diverse backgrounds. These are, for example, the "Passageproject Migrantenvrouwen", ${ }^{65}$ launched in 2016. Its objective was to begin a dialogue with immigrant women from non-Western cultures on the

${ }^{63}$ Eindrapportage Plan van aanpak Emancipatie en Integratie, http://www.emancipatie.nl/_documenten/emb/tk/29/29203/29203-030-bijlage.pdf (access 28.01.2021).

${ }^{64}$ M. de Gruijter, Kansen en belemmeringen bij maatschappelijke participatie van hoger opgeleide vrouwelijke vluchtelingen, https://www.verwey-jonker.nl/doc/participatie/ D8071871_def.pdf (access 28.01.2021).

${ }^{65}$ Nieüw Passageproject Migrantenvrouwen, https://www.passagevrouwen.nl/html/ index.php?pag $=, 845$ (access 15.02.2021). 
emancipation of Dutch women in the Netherlands; "Nederlands leren van de buurvrouw" 66 which encourages isolated Turkish and Moroccan women to learn Dutch at home; "De weg vinden in onze samenleving"67 aimed at lost African women in need and others. However, it should be emphasised once again that despite several years' effort, the effects of many initiatives are not fully satisfactory. It seems that in this case, a significant problem is the approach that does not give the gender issue sufficient and due consideration..$^{68}$ Nor does it, to a large extent, individually refer to individual, socially and culturally diverse minority groups, treating the diasporas of new women as homogeneous groups and often conforming to stereotypes. On the other hand, the Dutch tradition of collaborative actions results in multi-stakeholder cooperation in the integration of ethnic minorities. Municipalities, civil society organisations (foundations and associations), immigrant associations, and volunteer teams complement and reinforce each other in their activities. Thanks to their joint work and benefits resulting from sharing the acquired knowledge and experience, the position of immigrant/refugee women who often do feel the need to get involved in the labour market is strengthened. The municipalities use the help of immigrant organisations whose representatives (including former refugees) share their experience with the newly arrived and motivate them to act by following their own example. Volunteer groups, on the other hand, work on expanding social networks through their often informal approach to those in need. Non-profit organisations cooperating with municipalities deal with, inter alia, social/vocational counselling helping women build self-esteem. They also inform them about their rights, duties, and opportunities for social participation. These activities, and others related to them, are an important starting point for the process of raising the awareness of these women, and then making them realise the possibility of doing paid work and thus gaining financial independence.

${ }^{66}$ Nederlands leren met de buurorouw? Fa natuurlijk!, https://www.tijdschriftles.nl/ inhoud/tijdschrift_artikel/LE-23-135-21/Nederlands-leren-met-de-buurvrouw-Janatuurlijk (access $\overline{15} .02 .2021$ ).

67 Ibidem.

${ }^{68}$ Projects created by non-governmental organisations (including VluchtelingenWerk Nederland) mostly target mixed groups of women immigrants/refugees, women and men. For example: "Vluchtelingen Investeren in Participeren", "Vluchtelingen Inburgering en Arbeid", "Actueel - Start met Participeren" et al. More in: V. Gul-Rechlewicz, The Participation..., op.cit., pp. 113-118. 


\section{“White Men's Bastion”, the Voice of Halleh Ghorashi, an Iranian Refugee}

Halleh Ghorashi, the abovementioned researcher studying the issues of cultural diversity in the Netherlands along with the integration of immigrants and refugees in this country, points to the problem of the unequal treatment of women, especially of those with immigrant origins. As a refugee herself, ${ }^{69}$ she understands the problems faced by representatives of ethnic minorities in Western countries, including the Kingdom. Ghorashi believes that problems related to sexism and racism in the country are difficult to solve because, as she emphasises, it is difficult to discuss something that Dutch society does not want to admit to or treats as a taboo subject. ${ }^{70}$ The researcher maintains that the image of the Netherlands as a country that is open and fully tolerant towards immigrants requires redefinition. In her opinion, as long as this distorted image is not questioned, and the stereotypical perception of immigrants as social welfare beneficiaries (immigrant women expecting assistance, being dependent on men), the problem of discrimination and unequal treatment will be present in Dutch society. It will also be difficult to prevent the negative consequences of the unfair treatment of culturally different groups. ${ }^{71}$

Ghorashi, herself having immigrant origins, draws attention to the image of women from Islamic cultures in the Netherlands as being oppressed or isolated. In her opinion, it is necessary to break with this stereotype which is harmful to many Muslim women. ${ }^{72}$ The reasons for social isolation, as she claims, are very diverse. Therefore, an integration policy aimed at this group of newcomers requires a broader approach to recognise this diversity and not boil all the problems down to cultural issues. Thanks to the strategy understood in this way, the emancipation policy can focus on all women: economic immigrants, refugees, single mothers, women oppressed and exploited by men, and those who

${ }^{69}$ Halleh Ghorashi came from Iran to the Netherlands in 1988. She is currently working as a researcher at VU (Vrije Universiteit Amsterdam).

70 P. Breedveld, Halleh Ghorashi: Racisme en seksisme nauwelijks bespreekbaar in Nederland, Ad Valvas, onafhankelijk platform van de Vrije Universiteit Amsterdam (access 21.02.2021); https://www.advalvas.vu.nl/nieuws/halleh-ghorashi-racisme-enseksisme-nauwelijks-bespreekbaar-nederland (access 20.04.2020). See also H. Ghorashi, Waroom is racizme taboe in Nederland, in: Diversiteit en Discriminatie: Onderzoek naar processen van in- uitsluiting, eds. M. Davidović, A. Terlouw, Amsterdam University Press, Amsterdam 2015, pp. 180-200.

${ }_{71}$ H. Ghorashi, Waroom is racizme..., op.cit., p. 197.

72 H. Ghorashi, Culturalisering van de emncipatie..., op.cit. 
cannot find their place in Western culture. According to Ghorashi, the perception of women from the point of view of their cultural assimilation and backwardness seems to be highly problematic, because immigrant/ refugee women are also groups of motivated and independent women. It is underlined that their problem largely stems from stereotypes that seem to prevail in Western countries, including the Netherlands. This false perception of women coming from immigrant backgrounds, i.e. that they are passive and dependent on men, generates a false association of the relationship between an unfavourable living situation and a cultural model. According to the researcher, an equally disturbing issue is the perception of Islam as a religion that only generates backwardness and exclusion of women in Dutch society. However, stating that none Muslim women are "trapped" - as it is believed - in their own culture or dependent on religious conditions would be untrue. This complexity of the problem, highlighted by Ghorashi, aims to draw attention to the heterogeneous nature of the diaspora of immigrant/refugee women; they represent different attitudes, character traits, creativity or lack thereof, approach to entrepreneurship, and attitude to religion. It seems, therefore, that the previously mentioned Barslund aptly captured the ineffectiveness of the current policy towards the arrivals, calling the conducted strategy the use of "one size for all". ${ }^{73}$ The adopted course of action is not only incorrect but also brings with it a caricature of the image of immigrant/refugee women. Moreover, it often happens that this negative image of women is so strong that it results in an unreliable (stereotypically coloured) approach to them during training and integration courses. As a result, such meetings often take the form of "pedagogical talks" that do nothing but discourage this group of recipients from any action. ${ }^{74}$ Such a sustained image of passive and withdrawn women from minority backgrounds may also constitute a barrier for those who are active and entrepreneurial. ${ }^{75}$

Ghorashi's personal experience representing the scientific community is an excellent example to help illustrate this problem because the Dutch academic community, as she claims, is far from neutrality and focusing on scientific and research quality beyond divisions. ${ }^{76}$ The dominance of male

${ }_{73}$ M. Barslund, A. Bartolomeo, L. Ludolph, Gender Inequality and Integration of Non-EU. Migrants in the EU, CEPS. Policy Insight, no. 2016/06, CEPS, Brussels 2017.

${ }^{74}$ Ibidem.

75 P. Breedveld, Halleh Ghorashi: Racisme en seksisme nauwelijks bespreekbaar in Nederland, Ad Valvas, onafhankelijk platform van de Vrije Universiteit Amsterdam (access 25.04.2020); https://www.advalvas.vu.nl/nieuws/halleh-ghorashi-racisme-enseksisme-nauwelijks-bespreekbaar-nederland (access 20.02.2021).

76 Ibidem. 
scientists over female scientists, especially those from ethnically diverse backgrounds, is clear. It is visible in the area of, for example, the allocated funds for research, high positions in decision-making committees held by men, or university positions taken. Ghorashi vocalises her disagreement with the reality created in this way because immigrant women, as she argues, bring added value to science due to a different perspective on many research issues, characterised by cultural diversity. ${ }^{77}$ The problems raised by Ghorashi have been presented in a research paper by Renate van der Zee under the telling title "Bastion of White Men" ("Bastion van witte mannen"). ${ }^{78}$ Apart from Ghorashi, the paper gives voice to other researchers, who have been fighting for years against the exclusion of women from immigrant backgrounds, namely Isabel Hoving and Gloria Wekker. They devote attention to many issues including the discrimination and unequal treatment of not only poorly-educated immigrant women but also university students and university graduates. ${ }^{79}$ The latter group often either have difficulties accessing their dream job or zero possibility of pursuing their careers.

Ghorashi also strongly believes that integration policymakers give women from the Islamic culture and their emancipation too much focus. It is not the only group of women with a different culture that needs support, reminds the researcher. This excessive concentration on this group causes dissonance and a sense of rejection (marginalisation) among women from other culturally diverse backgrounds. The attention focused on uneducated immigrant/refugee women, often representing a conservative branch of the Islamic religion, means that well-prepared, highly educated women are left to fend for themselves or even, not uncommonly ${ }^{80}$ are exposed to (in)direct discrimination in various areas of life. ${ }^{81}$ Ghorashi points to the mutual harm in this respect, caused both to the affected women from immigrant diasporas and to the whole of Dutch society, who are thus losing an important segment of valuable citizens.

Therefore, it seems that the policy towards women from culturally diverse backgrounds should be sensitive to this diversity and use mainly positive, tested patterns, and stimulate various forms of alliances that

77 Ibidem.

${ }_{78}$ R. van der Zee, Bastion van witte mannen, HP/De Tijd No 09, 2016.

79 Ibidem.

${ }^{80} \mathrm{M}$. Esajas, $\mathcal{F}$ e moet twee keer zo hard werken, Racisme, discriminatieen en de sociaaleconomische positie van Surinamse Nederlanders, Amsterdam 2017, pp. 14-20, 52 et al., https://nucnet.nl/wp-content/uploads/2017/04/Je-moet-twee-keer-zo-hard-werken.Racisme-discriminatie-en-de-sociale-mobiliteit-van-Surinaamse-Nederlanders.pdf (access 19.02.2021).

${ }^{81}$ H. Ghorashi, Culturalisering van de emncipatievan..., op.cit. 
can support it. Current emancipation policies, according to Ghorashi, create tensions between women and make bonds almost impossible to form because the culture gap is too large. The broader dimension of this policy, focused on the individual problems of women, can create and strengthen ties between the various groups. After all, as everyone agrees, there is one particular community basis for all of them, such as childcare, which can connect women of different cultures and ${ }^{82}$ constitute a kind of springboard for the implementation of other necessary activities.

\section{Conclusions}

Over the years, the status of immigrant women and refugees in the Netherlands has improved, but still - as shown by numerous studies and reports - is not satisfactory. When compared to other immigrant women, refugee women maintain a large distance from the labour market. This is partly due to some cultural determinants, often related to their religions, such as Islam. An important problem, highlighted by the researchers, is the ineffective solutions concerning gender inequality in immigrant and refugee communities in key areas of integration. This is because the share of women, e.g. in the labour market, is much lower than that of men. This difference between the sexes is partially but not fully explained because, according to some experts on the subject, cultural traditions related to the gender hierarchy may be to blame, while others state that a common stereotype regarding the perception of women from ethnically diverse backgrounds that Western societies conform to is that they are withdrawn and reluctant to acculturate. This false perception of women from immigrant backgrounds affects not only those uneducated and passive people but also those of a creative and entrepreneurial nature, such as university graduates. Halleh Ghirashi, a refugee from Iran, currently a researcher, anthropologist, and professor at the Vrije Universiteit in Amsterdam who, despite many obstacles, fulfilled her dreams of settling down in the Netherlands, takes a strong stand on this issue. She raises the important problem of the need to change the policy towards women from cultures other than the Western one. She cites the need for critical thinking (rejecting the destructive cultural stereotypes) and looking at individual desires, needs, and problems of representatives of different cultures as a priority issue in the current policy towards ethnic minorities. Hers is not a lone voice in this matter. Increasing the participation of immigrant and refugee women in Dutch society refers to the need to

${ }^{82}$ Ibidem. 
increase efforts to support and empower women from allochthonous backgrounds. Experts suggest that the entities that offer this support (i.e. municipalities, non-profit organisations, groups of volunteers) redefine their attitudes towards recipients of aid programs/projects so that they feel the actual addressees of the activities carried out. At the same time, they call for the necessity to strengthen the support structures themselves so that they can work more efficiently based on a broad spectrum of the cultural needs of immigrant and refugee women. Finally, gender-sensitive measures, particularly important with regard to groups of isolated women, should become a decisive novelty in the change of approach to empower refugee and immigrant women.

The greatest challenge facing the movement of women from culturally and religiously diverse backgrounds in the Netherlands is creating trans-cultural alliances. Women from different cultures need to form bonds and start supporting each other in their fight against all signs of discrimination, unequal treatment, stereotypes, and marginalisation. The Netherlands is currently facing a new wave of emancipating immigrant women, especially a large group of highly educated women who have been excluded from the Dutch labour market for a long time. They are now starting to show their presence more and more increasingly.

\section{References}

Asylum Trends. Monthly Report on Asylum Applications in The Netherlands. Recent trends, Ministry of Security and Justice Immigration and Naturalisation Service (IND), IND Business Information Centre (BIC), Den Haag 2017, https://ind.nl/en/Documents/ATJune2017.pdf (access 3.02.2021).

Barslund M., Bartolomeo B., Ludolph L., Gender Inequality and Integration of Non-EU. Migrants in the EU, CEPS. Policy Insight, no. 2016/06, CEPS, Brussels 2017.

Breedveld P., Halleh Ghorashi: Racisme en seksisme nauwelijks bespreekbaar in Nederland, Ad Valvas, onafhankelijk platform van de Vrije Universiteit Amsterdam, 25.04.2020, https://www.advalvas.vu.nl/nieuws/ halleh-ghorashi-racisme-en-seksisme-nauwelijks-bespreekbaarnederland (access 20.02.2021).

Centraal Bureau voor de Statistiek, Van opvang naar integratie. Cohortstudie van recente asielmigranten, Den Haag 2017.

Centraal Bureau voor de Statistiek, Uit de startblokken. Cohortstudie naar recente asielmigranten, Den Haag 2018. 
de Gruijter M., Kansen en belemmeringen bij maatschappelijke participatie van hoger opgeleide vrouwelijke vluchtelingen, https://www.verwey-jnker. nl/doc/participatie/D8071871_def.pdf (access 28.01.2021).

de Gruijter M., Hoe zorgen we dat vluchtelingenvrouwen net zo vaak werk inden als mannen?, https://www.kis.nl/artikel/hoe-zorgen-we-datvluchtelingenvrouwen-net-zo-vaak-werk-vinden-als-mannen (access 11.01.2021).

de Gruijter M., ter Woerds S., Kansen en belemmeringen bijmaatschappelijke participatie van hoger opgeleide vrouwelijkevluchtelingen, Vooronderzoek voor het project 'Barrière of Carrière?', 2005.

de Ridder J., Andriessen I., Dekker P., Nederlanders dubbel over discriminatie, „Burgerperspectieven”, no. 2/2017, Sociaal en Cultureel Planbureau, 29.06.2017.

Eindrapportage Plan van aanpak Emancipatie en Integratie, http://www. emancipatie.nl/_documenten/emb/tk/29/29203/29203-030-bijlage.pdf (access 19.02.20 $\overline{2} 1$ ).

Esajas M., fe moet twee keer zo hard werken, Racisme, discriminatieen en de sociaaleconomische positie van Surinamse Nederlanders, Amsterdam 2017, https://nucnet.nl/wp-content/uploads/2017/04/Je-moet-twee-keer-zohard-werken.-Racisme-discriminatie-en-de-sociale-mobiliteit-vanSurinaamse-Nederlanders.pdf (access 19.02.2021).

Foundation for Political, Economic and Social Research, Istambul, Washington, Kair 2016.

From Refugees to Workers, Mapping Labour-Market Integration Support Measures for Asylum Seekers and Refugees in EU Member States, Volume II: Literature Review and Country Case Studies, Bertelsmann Stiftung 2016.

Gemeente Amsterdam. Vluchtelingenmonitor 2016, Gemeente Amsterdam, afdeling Onderzoek, Informatie en Statistiek, Amsterdam 2016.

Ghorashi H., Culturalisering van de emncipatie van migrantenvrouwen, http:// hallehghorashi.com/nl/wp-content/uploads/2010/12/Culturaliseringemancipatie-migrantenvrouwen.pdf (access 12.02.2021).

Ghorashi H., Waroom is racizme taboe in Nederland?, in: Diversiteit en Discriminatie: Onderzoek naar processen van in-uitsluiting, eds. M. Davidović, A. Terlouw, Amsterdam University Press, Amsterdam 2015.

Gul-Rechlewicz V., Science, Politics, Integration. Controversies over Dutch Immigration Policy, Compus, Kielce 2017.

Gul-Rechlewicz V., The Participation of Non-governmental Organizations in the Dutch Policy towards Refugees. The Role of VluchtelingenWerk Nederland, Compus, Kielce 2017.

Hinsberg A., Emancipatiemonitor: vrouwen met een migratiegrond blijven achter, KIS, 12.12.2018, https://www.kis.nl/artikel/emancipatiemonitor- 
vrouwen-met-een-migratieachtergrond-blijven-achter

(access

15.02.2021).

https://www.verwey-jonker.nl/doc/participatie/D8071871_def.pdf (access 11.02.2021).

Faarrapport Integratie 2016 (Annual Integration Report 2016), Centraal Bureau voor de Statistiek, Den Haag/ Heerlen/Bonaire 2016.

Jansen D., Immigratie en integratie het grootse probleem van Nederland, https://demonitor.kro-ncrv.nl/artikelen/immigratie-en-integratie-hetgrootste-probleem-van-nederland (access 21.02.2021).

Kansen en belemmeringen bij maatschappelijke participatie van hoger opgeleide vrouwelijke vluchtelingen, https://www.verwey-jonker.nl/doc/ participatie/D8071871_def.pdf(access 11.02.2021).

Kennisuitwisseling Movisie en Refugee Academy, Vluchtelingenvrouwen en werk: 'kijk naar de mogelijkheden!, https://www.movisie.nl/artikel/ vluchtelingenvrouwen-werk-kijk-naar-mogelijkheden (access 3.01.2021).

Kernciffers asiel en migratie, juni 2017, https://www.rijksoverheid.nl/ documenten/publicaties/2017/07/20/kerncijfers-asiel-en-migratiejuni-2017 (access 5.01.2021).

Kofman E., Female „Birds of Passage” a Decade Later. Gender and Immigrationin the European Union, "International Migration Review”, no. 33(2)/1999, DOI: https://doi.org/10.2307/2547698.

Leerkes A., Scholten P., Landen in Nederland. De vluchtelingenstroom in integratieperspectief, In opdracht van het Ministerie van Sociale Zaken en Werkgelegenheid, Rotterdam 2016.

Maliepaard M., Witkamp B., Jennissen R., Een kwestie van tijd? De integratie van asielzoekers: een cohortonderzoek (CAHIER, 2017-3), WODC, Den Haag 2017.

Ministerie van Onderwijs, Cultuur en Wetenschap, Emancipatie, Verschillende groepen vrouwen op de arbeidsmarkt, Den Haag 2018.

Nieuw Passageproject Migrantenorouwen, https://www.passagevrouwen.nl/ $\mathrm{html} /$ index.php?pag $=, 845$ (access 15.02.2021).

Obbink H., van de Wetering K., Over discriminatie hinken Nederlanders op twee gedachte, https://www.trouw.nl/nieuws/over-discriminatie-hinkennederlanders-op-twee-gedachten $\sim$ bb35b794/ (access 13.02.2021).

$O p$ de arbeidsmarkt, http://www.werkwijzervluchtelingen.nl/feitencigejfers/arbeidsmarkt.aspx (access 22.02.2021).

Opvangcapaciteit COA voor eind 2017 naar 31.000 plaatsen, 26.04.2017, https://www.coa.nl/nl/actueel/nieuws/opvangcapaciteit-coa-voor-eind2017-naar-31000-plaatsen (access 2.01.2021).

Overdijk T., Werkloosheid in Nederland hoger dan voor crisis, https://www. places.nl/nieuws/werving- \&-selectie/werkloosheid-in-nederlandhoger-dan-voor-de-crisis/ (access 3.02.2021). 
Pacek M., The Netherlands and the Migration Crisis, "Yearbook of the Institute of East-Central Europe", no. 15(3)/2017.

Pasamonik B., Women immigrants in Western societies. Emancipation and integration, https://www.academia.edu/17550426/Imigrantki_w spo\%C5\%82ecze\%C5\%84stwach_Zachodu._Emancypacja_i_integracja (access 23.03.2020).

Pessar P., Mahler S.J., Transnational Migration: Bringing Gender, „International Migration Review”, no. 37/2003, DOI: https://doi. org/10.1111/j.1747-7379.2003.tb00159.x.

Projecten in Nederland, https://www.knr.nl/pin/projecten.asp?pagina $\mathrm{id}=10$ (access 15.02.2021).

Radowicz J.A., Equal Rights for Woman: Nordic Solutions, "Studia i Materiały. Miscellanea Oeconomicae", no. 2(18)/2014.

Rath J., Minorisering. De sociale constructie van 'etnische minderheden', Sua, Amsterdam 1991.

Razenberg I., Kahmann M., de Gruijter M., „Mind the gap”: barrieres en mogelijkheden voor de arbeidsparticipatie van vluchtelingenvrouwen, KIS, Utrecht 2018.

Razenberg I., Kahmann M., Gruijter M., Monitor gemeentelijk beleid arbeidstoeleiding vluchtelingen 2017, Kennisplatform Integratie en Samenleving, Utrecht 2017.

Schmeets H., van Hoof M., Ontwikkelingen in ervaren nationale problemen, 2010-2014, Bevolkings trends, no. 6, CBS, Den Haag 2016.

van der Zee R., Bastion van witte mannen, HP/De Tijd no. 09/2016.

Vluchtelingenvrouwen en werk: kijk naar, https://www.movisie.nl/artikel/ vluchtelingenvrouwen-werk-kijk-naar-mogelijkheden (access 12.02.2021).

Vluchtelingenorouwen en werk: kijk naar mogelijkheden, https://www.movisie. $\mathrm{nl} /$ artikel/vluchtelingenvrouwen-werk-kijk-naar-mogelijkheden (access 12.02.2021).

Voortgangsrapportage. Emancipatie, maart 2019, Ministerie van Onderwijs, Cultuur en Wetenschap, https://www.womeninc.nl/Uploaded files/Zelf/ voortgangsrapportage-emancipatie-voor-de-tablet-of-smartphonetevens-printversie-en-digitoegankelijk.b30c05.pdf (access 23.02.2022).

Wansink H., Zijn Nederlanders toleranter geworden tegenover migranten?, Volkskrant, 13.12.2017, https://www.volkskrant.nl/columns-opinie/ zijn-nederlanders-toleranter-geworden-tegenover-migranten$\sim$ bebf8a3f/ (access 16.02.2021).

Werkloosheid daalt verder, DOI: https://doi.org/10.22456/1981-4526.105768. Wijkhuijs V., van Duin M., Vluchtelingencrisis 2015: Lessen uit de crisisnoodopvang, Instituut Fysieke Veiligheid, Arnhem 2017. 